\title{
Occurrence and recurrence of forest fires in Itatiaia National Park between 2008 and 2016
}

\author{
Isabela Braga Belchior ${ }^{l}$, Luis Marcelo Tavares de Carvalho ${ }^{I}$, Samantha Ramos Gomes ${ }^{l}$, \\ Flávio Carvalho Ferreiral , Raphaela Soares de Souza Pereira ${ }^{1}$, Gustavo Wanderley Tomzhinki², \\ Marcelo Souza Motta ${ }^{2}$

\footnotetext{
${ }^{1}$ Universidade Federal de Lavras (UFLA), Lavras, Brasil

${ }^{2}$ Instituto Chico Mendes de Conservação da Biodiversidade (ICMBio), Parque Nacional do Itatiaia, Brasil

*e-mail: isabela_bbelchior@hotmail.com
}

\begin{abstract}
Some ecosystems are adapted to fire disturbances, but as fires become recurrent in the same area, fire can cause drastic landscape changes resulting in loss of biodiversity. Thus, this study aimed to evaluate the occurrence and recurrence of forest fires for a period of 8 years in the interior and in the buffer zone of Itatiaia National Park (INP). The polygons of the burned areas were extracted from the INP Fire Report database. Since 2008, reporting polygons have been collected using GPS devices. Each polygon that delimits a burned area represents one occurrence. Therefore, the total number of occurrences in each year is represented by the number of polygons this year. The total area burned between 2008 and 2016 was 3435.64 hectares, corresponding to $4.3 \%$ of the study area. In this period, 354 occurrences were verified, and 2014 had 51 occurrences, the largest number found in the study. However, 2014 was not the year with the largest area hit by fire. The largest burned area occurred in 2010, with 1573,86 hectares. This fact can be explained by a single occurrence that reached 1255.11 hectares in the Campos de Altitude of Itatiaia upland. Inside the INP, areas with up to 5 fire recurrences that can be classified as anthropic fields and related to livestock use were verified. In the buffer zone, up to 6 recurrences were found, especially the lower part of the park and the areas near the rural communities of the municipality of Itamonte. The map of fire recurrence plus the survey of the causes of forest fires and the socioeconomic needs of fire use provides important subsidies for the planning and execution of specific strategies aimed at the protection and management of protected areas.
\end{abstract}

Keywords: INP, burned area, GIS 